\title{
Response of hazelnut hybrids (C. avellana $\times$ C. heterophylla) growth to nitrogen fertilization
}

\author{
Zhijun Li ${ }^{1,2}$, Xuemei Zhang ${ }^{2}$, Daoming Wang ${ }^{2}$, Ruifeng $\mathrm{Ma}^{2}$, Ming Xie ${ }^{2}$ and Lijuan Yang ${ }^{3}$ \\ ${ }^{1}$ College of Land and Environment, Shenyang Agricultural University, Shenyang, China \\ ${ }^{2}$ Economic Forestry Research Institute of Liaoning Province, Dalian, China \\ ${ }^{3}$ College of Land and Environment, Shenyang Agricultural University, Shenyang, China
}

\section{Summary}

Hybrid hazelnut of Corylus avellana L. and Corylus heterophylla Fisch. ex Trautv. is the potential economic forestry with higher economic values for China. Current recommendations of nitrogen (N) application rates for hazelnut production which are based on information from Corylus avellana may not be applicable to hybrid hazelnut. To clarify the effect of $\mathbf{N}$ application on the productivity of hybrid hazelnut seedlings, the released cultivars 'Dawei' and 'Yuzhui' were cultured under different nitrogen (as urea) rates: 0 (CK), 11 (T1), 22 (T2), 44 (T3), and 88 (T4) g N plant $^{-1}$, in the spring, two weeks after transplanting. The effects of nitrogen addition on growth, biomass partition, source-sink relationship, nutrient and light utilization of one-year-old hybrid hazelnut of Corylus avellana and Corylus heterophylla seedlings are studied. Comprehensive evaluation of productivity of two seedlings shows that the growth index and biometric index are of great significance in seedlings biomass accumulation. Biomass fitted values of hybrid hazelnut seedlings reached the highest value under 22 g N plant $^{-1}$.

\section{Keywords}

Eastern Filbert Blight, ammoniate, biomass,

photosynthesis, nitrogen recommendations

\section{Introduction}

Hybrid hazelnut is an economic fruit tree with higher economic values in China. It is a hybrid of Corylus avellana and Corylus heterophylla. Corylus heterophylla is an archaic Chinese hazelnut, which was usually regarded as an interesting edible nut from ancient times. It was conferred genetic resistance to Eastern Filbert Blight (Anisogramma anomola (Peck) E. Müll.), and had high cold hardiness resistance which can adapt well to the extreme minimum temperatures in North China. However, Corylus heterophylla cannot meet the market demand due to its small nut size (about 1.0 g per nut), little percent of kernel $(\leq 35 \%)$, and low productivity (about $300 \mathrm{~kg} \mathrm{ha}^{-1}$ ) (Weijiang et al., 1994). Corylus avellana, European hazelnut, was the most popular variety for commercial production worldwide (Braun et al., 2009). About 30 cultivars of European hazelnut were introduced into China from the USA and Italy from 1972-1998. However, European hazelnuts are sensitive to low temperatures; their yields were very low despite the tree growing well under low temperature, which greatly constrains their cultivation in horticulture in North China. In order to improve the yield and

\section{Significance of this study}

What is already known on this subject?

- Hybrid hazelnut is promising in China for its high economic value. The fertilization of $\mathrm{N}$ plays an important role in breeding healthy hybrid hazelnut seedlings.

What are the new findings?

- Proper application of N (no more than $22 \mathrm{~g} \mathrm{~N}$ plant $^{-1}$ in this study) will enhance the growth and development of hybrid hazelnuts. Excessive application of $\mathrm{N}$ will cause rooting damage, especially fibrous root.

What is the expected impact on horticulture?

- This study will provide significant advice on how to breed healthy hybrid hazelnut seedlings, which will reduce the losses of farmers and increase their income, and at the same time, lowers the risk of $\mathrm{N}$ loss.

nut quality, the hybrid breeding program of Corylus avellana and Corylus heterophylla was carried out in northern China since 1980, and 14 cultivars were released so far (Xie et al., 2014).

Hybrid hazelnuts of Corylus avellana and Corylus heterophylla which inherited advantages of their parents has been widely planted in China in recent years (Xie et al., 2014). However, no supportive management technology was developed for the planting of hybrid hazelnuts. Current recommendations for $\mathrm{N}$ fertilization of hazelnut are based on European hazelnut trees (Olsen, 2001). Although plenty of researches have been conducted on the nutrient management of European hazelnuts elsewhere, it may not be applicable to hybrid hazelnut in China due to the differences of soil, climate, genetics, and growing systems (Miljkovic and Jemric, 1997). For example, fertilization practices of European hazelnut were distinctly different between Oregon and the Mediterranean due to diverse climatic types (Strabbioli, 1994; Tous et al., 1994; Ferrran et al., 1997; Borges et al., 2001). As an essential nutrition, $\mathrm{N}$ plays an important role in the growth of tree and fruit of hybrid hazelnut. However, intensive application of $\mathrm{N}$ fertilizers at the wrong time will inhibit the growth or kill young seedlings, and as a consequence, reduce the yield and nut quality (Sanchez et al., 1995). Furthermore, excessive $\mathrm{N}$ fertilization may result in environmental pollutants (Weinbaum et al., 1992).

Therefore the aim of this study is to find the appropriate $\mathrm{N}$ fertilization rates for production of the hybrid hazelnut in Northern China. 
TABLE 1. Soil analysis data for the trial site Dalian, prior to planting.

\begin{tabular}{lccccc}
\hline Site & \multicolumn{5}{c}{ Attributes } \\
\cline { 2 - 6 } & $\mathrm{pH}$ & Available phosphorus & Available nitrogen & Available potassium & Organic matter \\
\hline Dalian & 6.9 & $32.8 \mathrm{mg} \mathrm{kg}^{-1}$ & $70.18 \mathrm{mg} \mathrm{kg}^{-1}$ & $213.8 \mathrm{mg} \mathrm{kg}^{-1}$ & $8.4 \mathrm{~g} \mathrm{~kg}^{-1}$ \\
\hline
\end{tabular}

\section{Materials and methods}

\section{Experimental site and plant materials}

The experimental site was located in Dalian $\left(121^{\circ} 37^{\prime} \mathrm{E}\right.$; $38^{\circ} 54^{\prime} \mathrm{N}$ ), Northeast China. The average annual temperature is $10^{\circ} \mathrm{C}$, and the mean annual precipitation is about $600 \mathrm{~mm}$. The studied soil was classified as brunisolic soil (FAO). Selected soil properties are listed in Table 1.

Two hybrid hazelnut cultivars, 'Dawei' and 'Yuzhui', were chosen according to their phenology. The planting materials were obtained from hazelnut propagators; the two cultivars were first-grade layered seedlings (shoot was about $100 \mathrm{~cm}$ high and $8 \mathrm{~cm}$ wide) with bare root. The characteristics of these two cultivars are shown in Table 2.

\section{Experimental design}

Five treatments were included for each cultivar in this study according to the $\mathrm{N}$ application rates: 0 (CK), 11 (T1), 22 (T2), 44 (T3), and 88 (T4) g N plant ${ }^{-1}$, and each treatment was replicated five times. Nitrogen was applied as urea. After the transplanting of seedling, urea was furrow-dressed surrounding the seedling with a $15-\mathrm{cm}$ distance from the trunk. The experiment was designed as a randomized complete block.

\section{Measurements}

Plant height was measured from the ground to the highest live bud by metre rule. Stem diameter was determined about $5 \mathrm{~cm}$ above the soil surface by slide caliper (Braun et al., 2009). Each plant was gently excavated from soil to protect its root from damage at the end of the growing season. Then, soils were washed from the root surface and the intact root system was scanned with an Epson digital scanner (Expression 10000XL 1.0, Epson Inc., Japan) and the WinRhizo Pro (S) v. 2004b software (Regent Instruments Inc., Canada) to quantitatively analyze the root architecture: total root length and surface area. Each whole plant was dried in paper bags at $60^{\circ} \mathrm{C}$, and then divided into leaves, roots and shoots, weighed, and their biomass partition were calculated. Nitrogen concentrations of leaf, shoot and root were determined by Dumas combustion procedure (Simonne et al., 1994).

The net photosynthetic rate $(\mathrm{Pn})$, stomatal conductance (Gs), intercellular $\mathrm{CO}_{2}$ concentration (Ci), transpiration rate $(\mathrm{Tr})$ and other photosynthetic parameters were measured by Li-6400 portable photosynthesis analyzer (LI-COR, Lincoln, Nebraska, USA). The photosynthetic parameters were collected from three healthy manure leaves of each tree be-

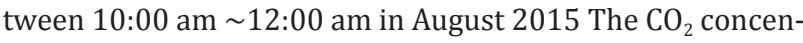
tration of the measuring chamber was fit to $409 \sim 459 \mu \mathrm{mol}$ $\mathrm{mol}^{-1}$, chamber temperature was controlled at $30^{\circ} \mathrm{C} \sim 35^{\circ} \mathrm{C}$, and relative air humidity was adjusted to $40 \sim 62 \%$.

\section{Statistical analysis}

All data were analyzed using One-way ANOVA and statistical significance was accepted at $P<0.05$. All analyses were conducted using the software IBM SPSS Statistics 20.

\section{Results}

\section{Effects of $\mathbf{N}$ fertilization on functional leaf properties of hybrid hazelnuts}

Single leaf dry weight ranged from $0.5 \sim 0.7 \mathrm{~g}$ in both two hybrid hazelnuts (Figure 1a). It increased with the increase of $\mathrm{N}$ application rate when the $\mathrm{N}$ application rate less than $22 \mathrm{~g} \mathrm{~N}$ plant $^{-1}$, then decreased as $\mathrm{N}$ application rate increased. However, all the $\mathrm{N}$ treatments significantly increased single leaf dry weight compared with CK. Similar tendency was observed in total leaf dry weight (Figure 1b), specific leaf weight (Figure 1c), leaf area (Figure 1d), and chlorophyll content (Figure 1f). However, $\mathrm{N}$ addition rate more than 44 and 88 g N plant $^{-1}$ significantly decreased Pn in 'Dawei' and 'Yuzhui' (Figure 1e), respectively.

\section{Effects of $\mathbf{N}$ fertilization on aboveground properties of hybrid hazelnuts}

All the aboveground properties firstly increased and then decreased with the $\mathrm{N}$ gradient (Figure 2), with the highest values found under T2 treatment. Stem diameter was significantly higher under T2 and T3 treatments than CK in 'Dawei', while all N treatments significantly increased it compared with CK in 'Yuzhui' (Figure 2a). High N application rate significantly inhibited the growth of 'Dawei', while all $\mathrm{N}$ treatments significantly enhanced the growth of 'Yuzhui' (Figure 2b). Stalk dry weight of 'Dawei' exhibited no higher $\mathrm{N}$ (44 and $88 \mathrm{~g} \mathrm{~N}$ plant $^{-1}$ ) effect, while all N treatments significantly increased stalk dry weight of 'Yuzhui' (Figure 2c). Only T2 significantly increased stalk number of 'Dawei', while no $\mathrm{N}$ effect was observed in the stalk number of 'Yuzhui' (Figure 2d). Except T4, all the other $\mathrm{N}$ treatments significantly increased branch length, irrespective of variety (Figure 2e). T1 treatment significantly decreased catkin number of 'Dawei', while T2 significantly increased it compared to CK (Figure 1f). All $\mathrm{N}$ treatments significantly increased catkin number of 'Yuzhui' compared to CK.

\section{Effects of $\mathrm{N}$ fertilization on root properties of hybrid hazelnuts}

Similar to aboveground properties, total root dry weight, tap root dry weight, fibrous root dry weight, root surface area, and root length firstly increased and then decreased with the increase of $\mathrm{N}$ application rate (Figure 3), with the highest values found under T2 (22 $\mathrm{g} \mathrm{N}$ plant $\left.^{-1}\right)$ treatment. T4

TABLE 2. The characteristics of the cultivars 'Dawei' and 'Yuzhui'.

\begin{tabular}{lcccc}
\hline Cultivars & Growth habit & Branching density & Nut shape & Kernel size $^{z}$ \\
\hline 'Dawei' & Erect & Dense & Long subcylindrical & $44 \%$ \\
'Yuzhui' & Semi-erect & Sparse & Ovoid & $43 \%$ \\
\hline
\end{tabular}

z The kernel size is presented as weight percentage of kernel to the whole fruit. 


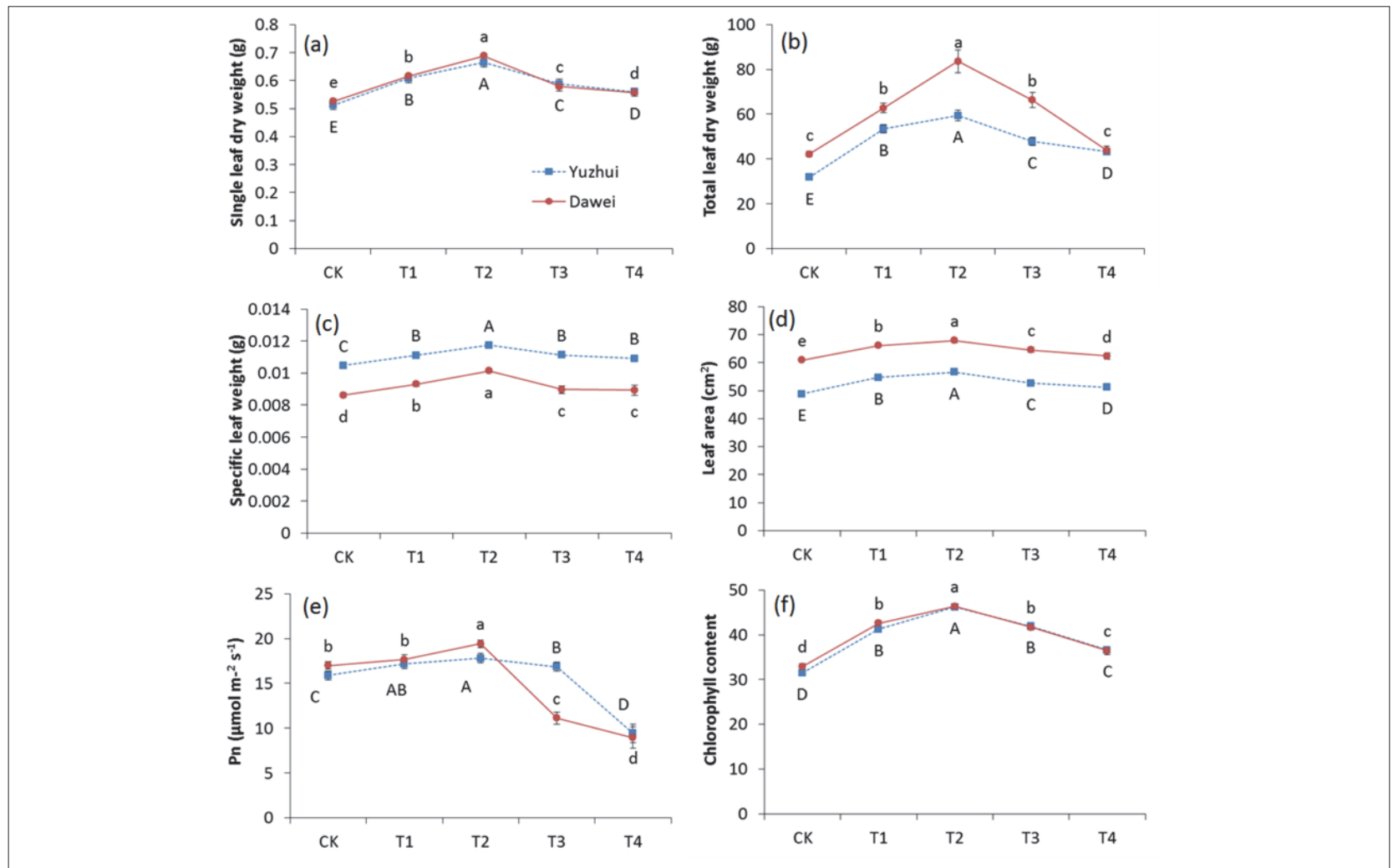

FIGURE 1. Responses of leaf properties of both two hybrid hazelnuts to $\mathrm{N}$ application: no $\mathrm{N}$ addition (CK); $11 \mathrm{~g} \mathrm{~N}$ plant $^{-1}$ (T1); $22 \mathrm{~g} \mathrm{~N}$ plant $^{-1}$ (T2); $44 \mathrm{~g} \mathrm{~N}$ plant $^{-1}$ (T3); and $88 \mathrm{~g} \mathrm{~N}$ plant $^{-1}$ (T4). (a) single leaf dry weight; (b) total leaf dry weight; (c) specific leaf weight; (d) leaf area; (e) net photosynthetic rate (Pn); (f) chlorophyll content. Data are represented as means \pm standard error $(n=4)$. Lowercase letters indicate significant differences between different treatments of 'Dawei' variety, and uppercase letters indicate significant differences between different treatments of 'Yuzhui' variety.
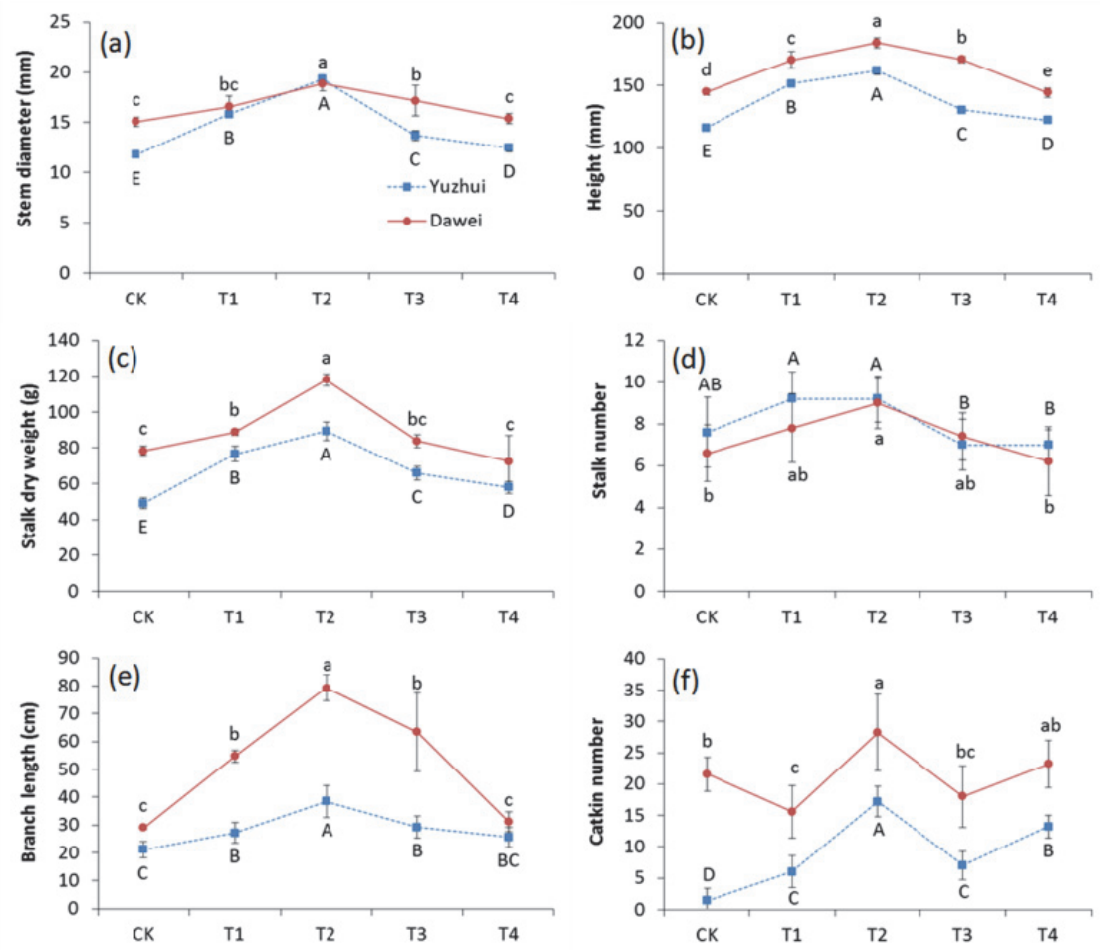

FIGURE 2. Responses of above ground properties of both two hybrid hazelnuts to $\mathrm{N}$ application: no $\mathrm{N}$ addition (CK); $11 \mathrm{~g} \mathrm{~N}$ plant $^{-1}$ (T1); 22 g N plant $^{-1}$ (T2); 44 g N plant $^{-1}$ (T3); and 88 g N plant $^{-1}$ (T4). (a) stem diameter; (b) height; (c) stalk dry weight; (d) stalk number; (e) branch length; (f) catkin number. Data are represented as means \pm standard error $(n=4)$. Lowercase letters indicate significant differences between different treatments of 'Dawei' variety, and uppercase letters indicate significant differences between different treatments of 'Yuzhui' variety. 

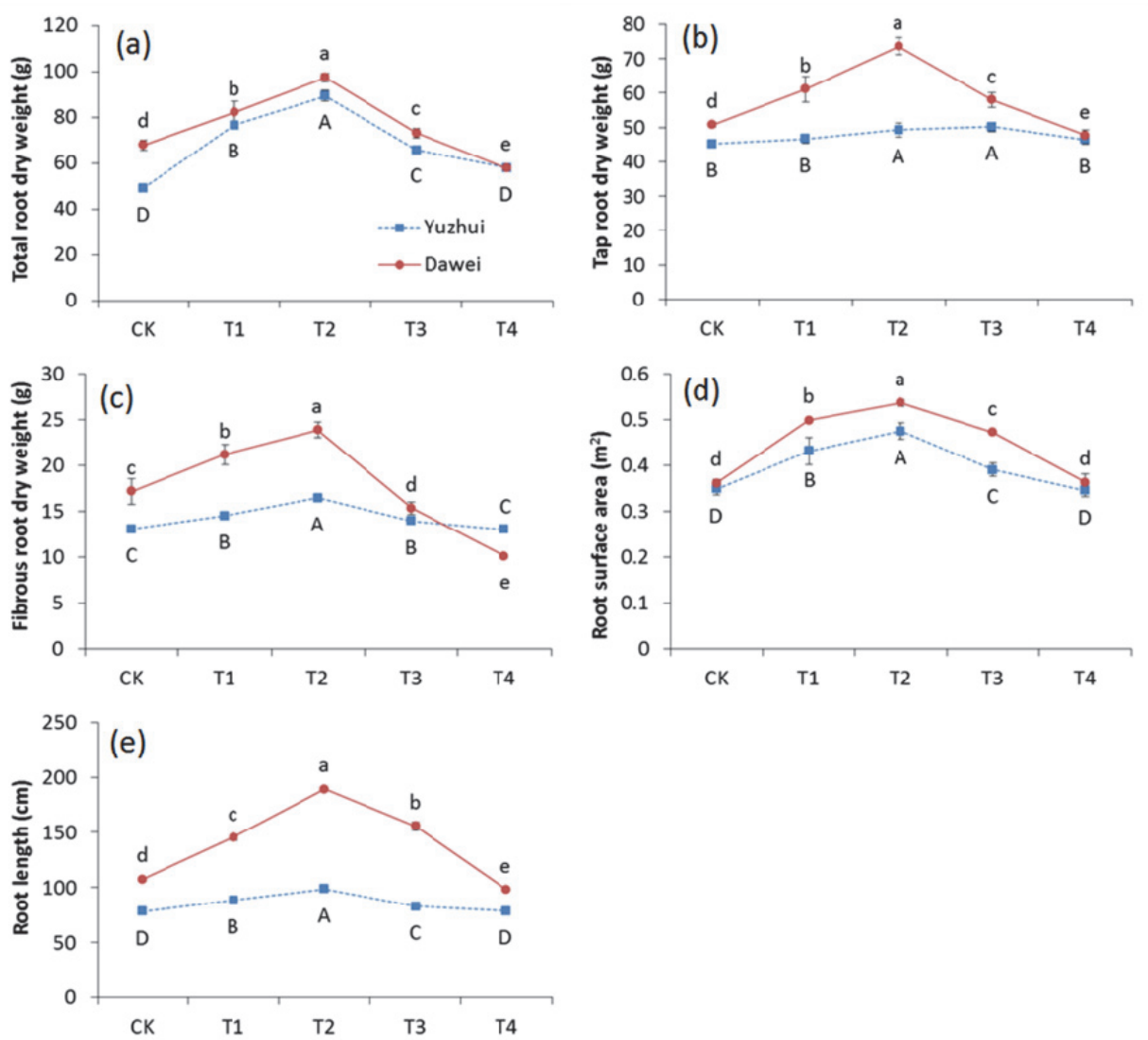

FIGURE 3. Responses of root properties of both two hybrid hazelnuts to $\mathrm{N}$ application: no $\mathrm{N}$ addition (CK); $11 \mathrm{~g} \mathrm{~N}$ plant $^{-1}$ (T1); $22 \mathrm{~g} \mathrm{~N}$ plant $^{-1}$ (T2); $44 \mathrm{~g} \mathrm{~N}$ plant $^{-1}$ (T3); and $88 \mathrm{~g} \mathrm{~N}$ plant $^{-1}$ (T4). (a) total root dry weight; (b) tap root dry weight; (c) fibrous root dry weight; (d) root surface area; (e) root length. Data are represented as means \pm standard error $(n=4)$. Lowercase letters indicate significant differences between different treatments of 'Dawei' variety, and uppercase letters indicate significant differences between different treatments of 'Yuzhui' variety.
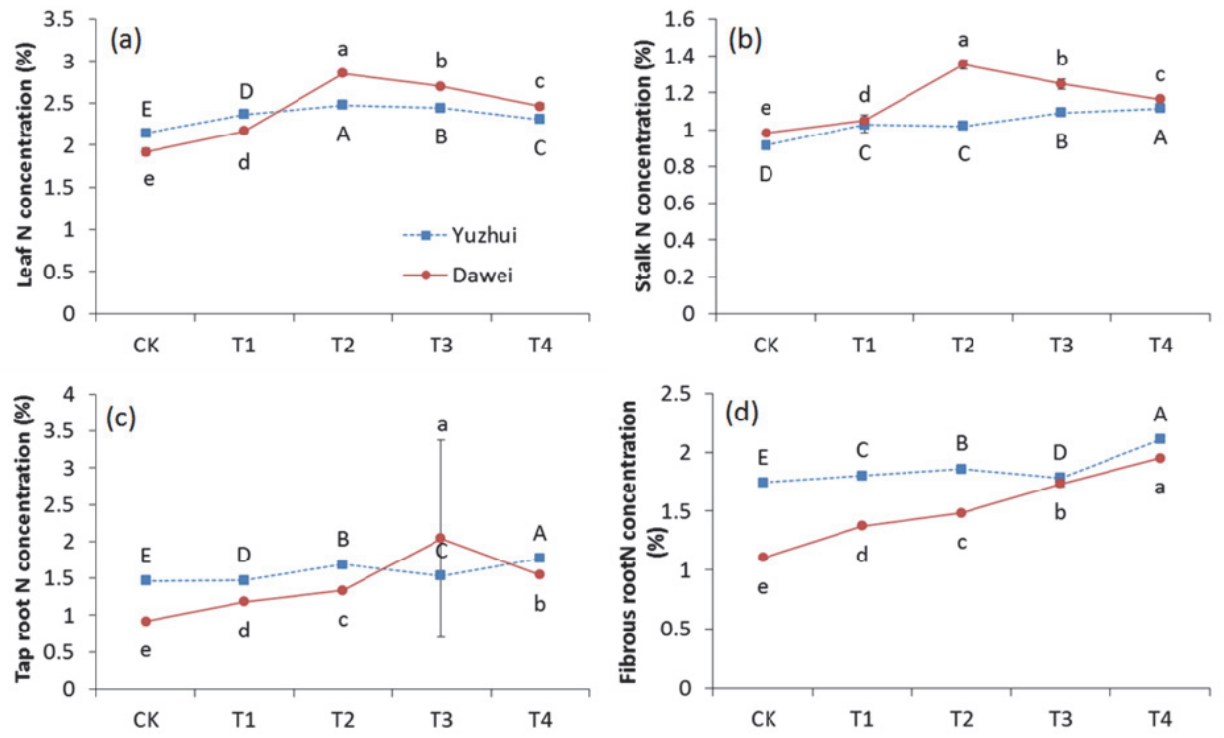

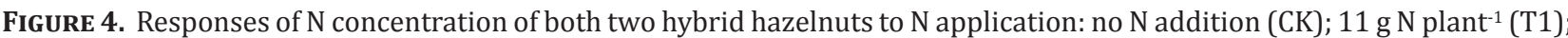
22 g N plant $^{-1}$ (T2); 44 g N plant $^{-1}$ (T3); and 88 g N plant $^{-1}$ (T4). (a) leaf N concentration; (b) stalk N concentration; (c) tap root $\mathrm{N}$ concentration; (d) fibrous root $\mathrm{N}$ concentration. Data are represented as means \pm standard error $(n=4)$. Lowercase letters indicate significant differences between different treatments of 'Dawei' variety, and uppercase letters indicate significant differences between different treatments of 'Yuzhui' variety. 
treatment significantly decreased total root dry weight, tap root dry weight, fibrous root dry weight, and root length of 'Dawei' compared to CK, while no negative effect of $\mathrm{N}$ addition was observed on the root properties of 'Yuzhui'.

\section{Effects of $\mathrm{N}$ application on tissue $\mathrm{N}$ contents of hybrid hazelnuts}

Leaf $\mathrm{N}$ concentration firstly increased, then decreased with the increase of $\mathrm{N}$ addition rate, with the highest $\mathrm{N}$ concentration found under T2 treatment (Figure 4a), regardless of variety. Similarly, stalk N concentration firstly increased then decreased under $\mathrm{N}$ addition gradient in 'Dawei' (Figure 4 b) However, stalk $\mathrm{N}$ concentration increased with the increase of $\mathrm{N}$ application rate in 'Yuzhui'. $\mathrm{N}$ concentrations of root (tap root and fibrous root) increased under the $\mathrm{N}$ gradient in 'Dawei' (Figures 4c and d). N concentration was lower under T3 treatment than T2 and T4 treatments in root (tap root and fibrous root) of 'Yuzhui'.

\section{Discussion}

Breeding of sturdy seedling is the basic of high yield and quantity of hazelnut tree (Shu, 1993). Generally, $\mathrm{N}$ is deemed as the key nutrition for the development of seedling (Gu et al., 1981). However, it is not recommended to apply $\mathrm{N}$ to European hazelnut seedling, because it will cause root burn and growth retarding (Olsen, 2001). Braun et al. (2011) suggested that the best way to keep the healthy growth of hybrid hazelnuts is applying no $\mathrm{N}$ or very low $\mathrm{N}$ in the Upper Midwest of the United States of America. However, our results indicated that supply of $\mathrm{N}$ in proper dosage (in this study $22 \mathrm{~g} \mathrm{~N}$ plant $^{-1}$ ) is necessary to keep the healthy growth of hybrid hazelnuts. Due to the differences of genetic and planting system, hybrid hazelnut management is sharply different from European hazelnut in China.

Nitrogen is especially important for photosynthesis since $\mathrm{N}$ is indispensable for the formation of chlorophyll and cytochromes in leaves (Taiz and Zeiger, 2002). Our results suggest that the dry weight, leaf area, specific leaf weight and chlorophyll content of functional leaves increased with the increase of nitrogen application rate when $\mathrm{N}$ application rate is less than $22 \mathrm{~g} \mathrm{~N}$ plant $^{-1}$ (Figure 1), which indicated that proper nitrogen application had a positive effect on retarding leaf senescence. In addition, compared with the control, the total leaf weight, stem diameter, stalk weight and plant height were significantly higher under low $\mathrm{N}$ fertilization rate (Figures 1 and 2). Nitrogen fertilization is conducive to enhance shoot growth (Ericsson, 1995; Millard and Neilsen, 1989), which did occur in our experiment. However, when the applied rate of $\mathrm{N}$ exceeds $44 \mathrm{~g} \mathrm{~N}$ plant $^{-1}$, these morphologically showed negative responses. In the functional leaves, the net photosynthetic rate is significantly lower under $88 \mathrm{~g} \mathrm{~N}$ plant $^{-1}$ than no $\mathrm{N}$ application, even if the leaf area and chlorophyll content did not decrease. The net photosynthetic rate is a common indicator of leaf assimilation and related to dry matter accumulation of plants. The lower net photosynthetic rate may be due to less formation of fibrous root (Figure 3) and poor water absorbing power under nitrogen stress. It can be concluded that logical applications of $\mathrm{N}$ can promote the growth and development of the aboveground part of the two hybrid hazelnuts, delay the senescence of leaves, and increase the reserve of nutrients (indicated as stem diameter). However, excessive nitrogen fertilization would exhibit negative effects.

Application of $\mathrm{N}$ fertilizer can influence root growth, structure and physiological function. Our results suggest that an appropriate amount of $\mathrm{N}$ fertilization could promote the growth of the root system and increase the dry matter of each type of root (Figure 3). Application of $\mathrm{N}$ fertilizer had the most obvious effect on the fibrous root system (Figure $3 \mathrm{c}$ ). When the applied amount of $\mathrm{N}$ exceeds $44 \mathrm{~g} \mathrm{~N}$ plant $^{-1}$, it firstly inhibits the growth of the fibrous root system, which can weaken the capacity to absorb water and other nutrients.

We found that $\mathrm{N}$ concentrations in leaf and stalk were not increased with the increase of $\mathrm{N}$ application rate, even if the $\mathrm{N}$ concentration increased in the root (Figure 4). This may ascribe to, first, the decrease of plant root, especially fibrous root, which can reduce the capacity of $\mathrm{N}$ transport from soil solution to plant; second, high $\mathrm{N}$ concentration in soil solution will cause an obstacle of $\mathrm{N}$ uptake by root. This study suggests that proper application of $\mathrm{N}$ (no more than $22 \mathrm{~g} \mathrm{~N}$ plant $^{-1}$ ) will result in the accumulation of $\mathrm{N}$ in aboveground tissues. In order to develop vigorous seedlings, appropriate amount of $\mathrm{N}$ fertilizer are needed, rather than no $\mathrm{N}$ addition. However, when excessive $\mathrm{N}$ fertilizer is applied, it will cause injury to the fibrous root system, and increase the risk of $\mathrm{N}$ loss.

\section{Conclusions}

Our results indicate that the application of $\mathrm{N}$ fertilizer can promote the growth of hybrid hazelnut seedlings by providing adequate nutrition and photosynthate. However, excessive $\mathrm{N}$ application may cause nitrogen stress, which will suppress the development of roots, especially fibrous roots, and photosynthesis of leaf, subsequently impact plant yield and nut quality. In this experiment, we recommend that the application rate of $\mathrm{N}$ should be less than $22 \mathrm{~g} \mathrm{~N}$ plant $^{-1}$, which could promote the growth and development of the studied hybrid hazelnut seedlings.

\section{References}

Borges, O.M.P., Carvalho, J.L.R.S., Silva, A.P., and Santos, A. (2001). Effects of foliar boron sprays on yield and nut quality of 'Segorbe' and 'Fertile de Coutard' hazelnut. Acta Hortic. 556, 307-312.

Braun, L.C., Gillman, J.H., and Hoover, E.E. (2011). Nitrogen fertilization for new plantings of hybrid hazelnuts in the Upper Midwest of the United States of America. Canadian J. Plant Sci. 91(4), 773-782. https://doi.org/10.4141/cjps2011-015.

Braun, L.C., and Gillman, J.H. (2009). Fertilizer nitrogen timing and uptake efficiency of hybrid hazelnuts in the Upper Midwest USA. HortSci. 44(6), 1688-1693.

Ericsson, T. (1995). Growth and shoot:root ratio of seedlings in relation to nutrient availability. Plant and Soil 62, 168-169, 205-214. https://doi.org/10.1007/BF00029330.

Ferran, X., Tous, J., and Romero, A. (1997). Boron does not increase hazelnut fruit set and production. HortSci. 32, 1053-1055. https:// doi.org/10.21273/HORTSCI.32.6.1053.

Gu, M.R., Shu, H.R., Li, W.W., and Huang, H.C. (1981). The variation of nitrogen nutrition within the plant in a year's cycle. Acta Hortic. Sinica $8,21-28$.

Miljkovic, I., and Jemric, T. (1997). Genetic specificity of mineral nutrition of hazelnut trees. Acta Hortic. 445, 441-448. https://doi. org/10.17660/ActaHortic.1997.445.57.

Millard, P., and Neilsen, G.H. (1989). The influence of nitrogen supply on the uptake and remobilization of stored $\mathrm{N}$ for the seasonal growth of apple trees. Ann. Bot. 63, 301-309. https://doi.org/10.1093/ oxfordjournals.aob.a087746. 
Olsen, J. (2001). Nutrient management guide-hazelnut. Ext. Serv. Bull. EM8786 (Oregon State University). http://extension.oregonstate. edu/catalog/pdf/em8786-e.pdf.

Pilon, P. (2006). Perennial Solutions, a Grower's Guide to Perennial Production (Batavia, IL: Ball Publ.).

Sanchez, E.E., Khemira, H., Sugar, D., and Righetti, T.L. (1995). Nitrogen management in orchards. In Nitrogen Fertilization in the Environment, P.E. Bacon, ed. (New York: Marcel Decker), p. 327-380.

Shu, H.R. (1993). Physiology of Temperate Fruit Trees. (Beijing: Agriculture Press).

Simonne, E.H., Mills, H.A., Jones, J.B., Smittle, D.A., and Hussey, G.G. (1994). A comparison of analytical methods for nitrogen analysis in plant tissues. Commun. Soil Sci. Plant Anal. 25, 943-954. https://doi. org/10.1080/00103629409369090.

Strabbioli, G. (1994). Mineral and organic fertilization of the hazelnut (Corylus avellana) in central Italy. Acta Hortic. 351, 429. https://doi. org/10.17660/ActaHortic.1994.351.46.

Taiz, L., and Zeiger, E. (2002). Plant Physiology, $3^{\text {rd }}$ ed. (Sunderland, MA.: Sinauer)

Tous, J., Girona, J., and Tasias, J. (1994). Cultural practices and costs in hazelnut production. Acta Hortic. 351, 395-418. https://doi. org/10.17660/ActaHortic.1994.351.44.

Weijiang, L., Ming, X., and Wanying, X. (1994). Studies on hazelnut breeding in Northern China. Acta Hortic. 351, 59-66. https://doi. org/10.17660/ActaHortic.1994.351.5.

Weinbaum, S.A., Johnson, R.S., and DeJong, T.M. (1992). Causes and consequences of overfertilization in orchards. HortTech. 2, 112-121. https://doi.org/10.21273/HORTTECH.2.1.112b.

Xie, M., Zheng, J.L., and Wang, D.M. (2014). Achievements and perspective in hazelnut breeding in China. Acta Hortic. 1052, 41-44. https://doi.org/10.17660/ActaHortic.2014.1052.4.

Received: May 12, 2017

Accepted: Sep. 10, 2017

Addresses of authors:

Zhijun Li1,2, Xuemei Zhang ${ }^{2}$, Daoming Wang ${ }^{2}$, Ruifeng $\mathrm{Ma}^{2}$,

Ming $\mathrm{Xie}^{2}$ and Lijuan Yang,*

${ }^{1}$ College of Land and Environment, Shenyang Agricultural

University, Shenyang 110866, China

${ }^{2}$ Economic Forestry Research Institute of Liaoning

Province, Dalian 116031, China

${ }^{3}$ College of Land and Environment, Shenyang Agricultural

University, Shenyang 110866, China

*Corresponding author; E-mail: syou_ylj@163.com 